\title{
The Determinants of Vote Buying: The Profile of Typical Vote 'Sellers'
}

In the preceding chapter, I showed how prevalent vote buying is in Indonesian elections, even by international standards. The findings offered a systematic confirmation of thus far largely anecdotal accounts of political clientelism in Indonesia. Despite the ubiquity of such practice and a recent surge in publications on the topic (e.g. Aspinall, 2014; Allen, 2015; Aspinall and Sukmajati, 2016; Amick, 2016; Aspinall et al., 2017; Tawakkal et al., 2017), surprisingly the question of what types of individuals are targeted by vote buying remains largely unexplored. Accordingly, this chapter focuses on the analysis of the individual-level determinants of targeting of vote buying and provides a comprehensive profile of the typical vote 'sellers.' I examine a wide range of variables that are generally believed to be the determinants of such electoral strategies. The final part of this chapter identifies the most striking aspects of vote buying in the national legislative elections.

One of the key findings of this chapter is that voter identification with political parties is consistently and significantly linked to vote buying. The closer the ties of a voter to a political party, the more likely that voter is to receive offers of vote buying. My post-legislative election data also shows that, contrary to prior expectations, most of the variables associated with modernisation theory have little correlation with vote buying. The insignificance of socio-economic factors indicates that the targeting of vote buying in the national parliamentary elections can be best explained in terms of party identification rather than the modernisation paradigm. 


\subsection{Perspectives on Electoral Clientelism}

In comparative studies on electoral clientelism, discussion of the determinants of vote buying at the individual level typically focus on the issue of target selection. As discussed in Chap. 1, because they have limited budgets, political machines aim to efficiently spend their resources on those voters most likely to respond positively to vote-buying attempts (i.e. voters who are most likely to commit their vote as a result of a vote-buying operation). Additionally, since ballot secrecy prevents candidates and brokers from unequivocally verifying whether recipients of payments reciprocate with their votes, it is essential for them to identify those voters who aren't only most likely to be influenced by vote buying but are also most reliable in delivering a vote.

Broadly, the literature on electoral clientelism has identified three factors explaining why some individuals are more likely than others to be targeted with vote buying: socio-economic and demographic factors; levels of civic engagement; and citizens' political attitudes. The first school of thought focuses on a quasi-determinist view of electoral clientelism that is congruent with arguments made by modernisation theorists. According to this camp, clientelism is best described as a pre-modern form of political and social relations, involving mostly lower class citizens (e.g. Lipset, 1959; Scott, 1972). Thus, it is an intrinsic element of 'third world' politics, affecting countries that are relatively poor and have low rates of literacy. They aren't 'modern,' say Andrews and Inman (2009: 6). Flowing from this conception of clientelism is the inverse argument that successful democratisation is only possible in polities with sufficiently high levels of economic development. Accordingly, as Hicken (2011: 299) explains, "clientelism appears to be more prevalent in developing countries, and within nations, noting that poorer voters appear to be more susceptible to clientelist offers than richer voters."

Many scholars therefore draw a connection between different dimensions of socio-economic modernisation and the prevalence of clientelist exchanges (e.g. Jensen and Justesen, 2014; Brusco et al., 2004). Such scholars believe that poor people are more attracted by vote buying than wealthier citizens. Stokes (2007b: 618) introduces the model of a high discount rate, explaining that "poor people are risk-averse and hence value more highly a bag of goodies in hand today than the promise of redistributive public policy tomorrow." The poor discount future programmatic benefits because future rewards are less certain and concrete than 
the ones they can collect now (Stokes, 2007a: 94). The literature on electoral clientelism has also emphasised the effects of education, proposing that low education makes citizens more vulnerable to vote buying (Kitschelt and Wilkinson, 2007).

Still within this modernisation paradigm, some scholars have suggested that variation in patterns of vote buying can result from different places of residence. For example, Hicken (2007a: 56) argues that vote buying is less likely in urban areas, partly due to the diminishing role in such settings of traditional patron-client networks through which a candidate can deliver material benefits. In addition, according to Hicken (2007a: 56), people who live in rural areas are more likely to be prone to vote buying because income and education levels are higher in urban areas and there are greater demands for public goods in urban areas, where residents are concerned about issues such as traffic congestion, public transportation, and garbage collection.

The focus of many authors advancing the economic modernisation approach has been on the conceptualisation of the argument and case studies that support it (Hicken, 2011; Scott, 1972; Jensen and Justesen, 2014). Based on these studies, as Hicken (2011: 297) put it, "clientelism was bound to disappear as countries modernised both economically and democratically." For that reason, vote buying appears to be endemic in many developing countries - and almost exclusively limited to them too. Although the assumptions put forward by the modernisation camp seem to be plausible, the developmentalist argument fails to explain why clientelist networks remain influential in relatively wealthy and highly educated nations, such as Japan (Kitschelt, 2007), Belgium (Kitschelt, 2007), Austria (Kitschelt, 2007), and Italy (Kitschelt, 2007). Such cases challenge the conclusions of the modernisation school within clientelism studies.

A second group trying to explain which voters get targeted most by vote buying has concentrated on civic engagement. In order to facilitate clientelistic exchange, many politicians make use of informal and formal organisations with large numbers of members. As a result, people who are involved in mass organisations are expected to be particularly exposed to vote buying. In the Philippines, Cruz (2014) argues that voters who are actively engaged in social networks are disproportionately targeted for vote buying. Gonzalez-Ocantos and his colleagues (2012: 212) found a similar conclusion, showing that Nicaraguans who actively engage in meetings held by civic associations are "far more likely to report vote buying than those who never attend." This is partly because such social 
organisations provide norms of reciprocity that can be used to mobilise support through particularistic electoral mobilisation and to ensure that recipients of patronage actually reciprocate with their votes (Callahan, 2005: 496).

Similarly, in the case of Thailand, Callahan (2005) suggests that civic associations are responsible for the emergence of new forms of electoral corruption and vote-buying practices at election times. As theoritised by Putnam (1993: 167), networks of civic engagement and norms of reciprocity are highly correlated since the two are an important feature of social capital. In this concept, norms of reciprocity are one vital aspect of the social capital that can facilitate clientelist exchanges. Cultural norms of gift giving, according to this approach, create a social atmosphere conducive to quid pro quo offers. This atmosphere, in turn, breeds a culture of mutual favours in which parties or candidates are happy to buy votes and voters are happy to 'sell' their vote in exchange for payment or other material benefits. Finan and Schechter (2012), therefore, argue that vote buying is inherently self-enforcing due to the existence of social norms of reciprocity.

A third camp of scholars has emphasised a potential link between electoral clientelism and political attitudes (e.g. Manzetti and Wilson, 2009; Banegas, 1998; Carreras and Irepoglu, 2013). Generally, political attitudes include components such as party identification, efficacy, political interest, political information, political trust, political participation, and support for democracy (Verba et al., 1995). Regarding party identification, scholars have offered no definitive conclusion on whether this component of political attitudes predicts the likelihood of receiving offers of vote buying. On the contrary, this issue is hotly debated. As we have seen, some scholars argue that payment for votes targets swing, or ideologically indifferent, voters (meaning that strong party identification would be negatively correlated with vote buying). As discussed thoroughly in Chap. 1, some even argue that providing money or private goods to those who are close to, or ideologically proximate to, any political party is wasteful (Lindbeck and Weibull, 1987; Dixit and Londregan, 1996; Stokes, 2005). In contrast, other authors suggest that political parties tend to focus their vote-buying efforts on their partisan, loyal voters whose turnout can be maximised-which would mean that high levels of party identification should predict vote buying (Cox and McCubbins, 1986; Nichter, 2008; Gans-Morse et al., 2014; Diaz-Cayeros et al., 2012; Stokes et al., 2013). 
Another dimension of political attitudes that might be relevant to political clientelism is political efficacy, that is, the citizenry's ability to influence government decisions, their belief that government cares what people think, and belief that government will respond to their demands. Reef and Knoke (1999: 414) define political efficacy as "an individual's sense of personal competence in influencing the political system." Political efficacy is adversely related to political alienation or political powerlessness, which refers to "a person's perceived inability to influence governmental policy" (Ibid., 414). Some scholars found a link between low levels of efficacy and vote buying. In Benin, for instance, material rewards offered by parties during elections are seen as an expression of political alienation, in which vote sellers were more likely to feel powerless about government and perceive politics as meaningless (Banegas, 1998: 78-79). Kerkvliet (1991: 231) found a similar pattern in the Philippines, where villagers tend to receive material benefits as "practically their only opportunity to get anything from people in government." In this view, disempowered citizens view elections as a momentary opportunity to "stake a rightful claim to the resources of those higher up" (Schaffer and Schedler, 2007: 26).

A further political attitude dimension that potentially correlates with electoral clientelism is political information. Grossman and Helpman (1996) suggest that 'uninformed voters' will be the most likely targets of clientelist campaign strategies. Vicente and Wantchekon (2009: 302) come to a similar finding, arguing that informed voters are more likely to support politicians who run programmatic campaigns and will stay away from material, particularistic strategies.

The next potentially relevant component of political attitudes is political interest, defined as "the degree to which politics arouses a citizen's curiosity" (Van Deth, 1989: 278). Some scholars suggest that linkages may exist between such interest and exposure to clientelist exchanges (e.g. Carreras and Irepoglu, 2013). An interested citizen, according to this view, is likely motivated to participate in elections without material rewards. This psychological variable is therefore believed to have a negative relationship with clientelist mobilisation. Moreover, an interested citizen is assumed to be efficacious and informed, linking political interest with other factors mentioned above. Generally, interested voters are expected to support parties or candidates who rely on public policy campaigns, while uninterested voters are expected to respond to vote-buying exchanges. 
Another related component of political attitudes that has started to receive scholarly interest in clientelism is political trust (Manzetti and Wilson, 2009). Political trust is defined in the literature as a basic evaluative orientation towards the political system (Citrin and Muste, 1999; Inglehart, 1999). While related to political efficacy, trust levels are more generally about the citizenry's evaluation of existing political institutions. In short, political efficacy is an input, while trust in institutions is an output of the political system (Almond and Verba, 1963). Manzetti and Wilson (2009) argue that clientelist politics and trust in political institutions are strongly related. They found that in countries where political and government institutions are weak and patron-client relationships are strong, voters tend to support corrupt leaders or parties from whom they expect to receive material benefits. Accordingly, voters with lower levels of trust towards political institutions are believed to build transactional relations with political parties and 'sell' their votes to candidates providing private goods and favours.

Electoral participation is another political attitude dimension that has become a matter of debate in the literature on clientelism. There has been a growing discussion about whether vote buying increases or decreases voter participation in elections. Using a field experiment in West Africa, Vicente (2013) found strong evidence that vote buying increases participation. Similarly, Carreras and Irepoglu (2013: 616) suggest that the distribution of electoral rewards is effective in mobilising voters in Latin America. In Egypt, Blaydes (2011) concludes that voters exercised their right to vote because they expected benefits (to be sure, she was describing elections under Mubarak's authoritarian rule). Nonetheless, other studies have produced contradictory findings. In Nigeria, Bratton (2008: 15), for instance, found that vote buying decreases individuals' electoral participation, suggesting that along with electoral violence, clientelist exchanges trigger disillusionment among the electorate, leading them to exit the political process.

A final attitudinal variable that might interrelate with political clientelism is support for democracy. It is generally held among scholars that clientelist exchanges are inimical to democracy (Stokes, 2005; Keefer, 2007; Kitschelt and Wilkinson, 2007). Stokes (2005: 316) argues that vote buying is undemocratic because it involves 'perverse accountability.' Instead of politicians being accountable to voters, she explains, where vote buying happens, voters are held accountable for their vote. Hence, it 
might be inferred that those who strongly support democracy would be less likely to engage in vote buying, and vice versa.

In sum, there are three broad conceptual frameworks that might affect the magnitude of vote buying: socio-economic factors, involvement in civic organisations, and political attitudes. In the next sections, I draw specific hypotheses from these three broad areas of inquiry and test them by analysing the dataset available to this study.

\subsection{Hypotheses}

\subsubsection{Vote Buying and Modernisation Theory}

As noted above, many scholars believe that socio-economic factors, such as income level and education, shape how widespread vote buying (Brusco et al., 2004; Vicente, 2013) becomes. Poor voters are believed to be significantly more vulnerable to such practices than wealthier ones. If this is true, then I expect to find that the poorer a voter, the more likely he or she is to experience vote buying. Another important aspect of modernisation that is believed to correlate with exchanges of material benefits for votes is education (Vicente, 2013). Indeed, variables of education and income are often highly correlated: people with lower education usually generate lower incomes than those with higher education, and vice versa. Consequently, less-educated individuals are expected to be more intensively exposed to vote buying than well-educated people. The hypothesis is: the less educated a voter, the more likely he or she is to experience vote buying. Additionally, as we have seen, differences in voters' geographical location are also believed to influence the potential for electoral clientelism. Here, the hypothesis is: a voter who lives in a rural area is more likely to experience vote buying than a voter residing in an urban area.

\subsubsection{Vote Buying and Civic Engagement}

As explained above, networks of civic engagement are typically used by clientelist actors to distribute patronage resources (Callahan, 2005). Virtually everywhere in the world, vote buying isn't legal. Therefore, politicians pursuing vote buying are forced to be discreet. However, it is difficult to engage large numbers of voters discreetly with vote-buying attempts (Hicken, 2007a, 2007b). Accordingly, they find ways to disguise their vote-buying attempts by, for instance, penetrating informal and formal 
organisations and packaging their clientelist offers in religious or social assistance terms. Such patterns have led to claims that social organisations - and their members - are more likely to be targeted by vote buying than individual voters without such links. If this is correct, the more deeply involved a voter is in social organisations, the more likely be or she is to be offered vote buying.

\subsubsection{Vote Buying and Political Attitudes}

We have also seen that extant explanations for electoral clientelism also include political attitudes, comprising several components. Concerning party identification, some scholars believe that voters who don't identify with a particular party (i.e. swing voters) tend to receive more material rewards. If this proposition is true, I expect to find that the more nonpartisan a voter is, the more likely he or she is to accept vote buying. A negative finding with regard to this hypothesis would direct us towards the core-voter model. Another aspect of political attitudes is political efficacy. With respect to efficacy, much of the literature suggests that clientelist exchanges are an indication of lower efficacy or an expression of political alienation. The hypothesis for this study, then, is the lower efficacy a citizen has the more likely he or she is to engage in vote buying.

Similarly, some literature claims that uninformed voters are more likely to be targeted by vote buying. If this claim is correct, we must hypothesise that individuals with increased access to information are less likely to receive offers of vote buying. The literature also suggests that voters with low levels of political interest are more susceptible to clientelist offers. If so, the more uninterested a citizen is in politics, the more likely he or she will be experiencing vote-buying attempts. With regard to political trust, there is an increasing perception that low levels of trust in political institutions lead to higher levels of vote buying. If so, it is plausible to hypothesise that the lower a voter's trust in political institutions, the more vulnerable she or he is to vote buying. In addition, much of the literature on clientelism also claims that participation in elections increases the likelihood of being targeted clientelist offers. If so, voters who participate in the election are more likely to experience vote buying. Finally, a widely held view among scholars is that clientelism runs counter to democratic principles, implying that those who strongly support democracy will stay away from such exchanges. Thus, I expect to find that those who support democracy are less likely to engage in vote-buying operations. 


\subsection{Measures of Modernisation Theory, Civic Engagement, and Political Attitudes}

In order to test the hypotheses developed above, this section introduces the independent variables needed to calculate the validity of the claims. As presented in Chap. 2, the dependent variables of my post-election survey in April 2014 are an experience, that is, being targeted by vote buying used to determine factors that explain why some individuals were more likely than others to receive offers of vote buying. The central independent variables, on the other hand, include socio-economic demographics, civic engagement, and a set of political attitudes, including party identification.

\subsubsection{Modernisation Theory}

I employ three common indicators of the modernisation argument: poverty, urban-rural domicile, and education. First, in the dataset, I use a single 12-point scale item to measure an individuals' income level. This measure asked: "On monthly average, how much is the gross income of your household?" Income is a continuous variable that reports the respondent's gross household income per month, coded on a scale from 1 to 12 , where 1 indicates that the respondent's income per month is under IDR $200,000.00$ (approximately US\$17.60) and 12 indicates over IDR 4,000,000.00 (approximately US\$352).

Second, it also identifies respondents' domicile based on a simple ruralurban dichotomy. This dichotomy, in turn, is drawn from an official ruralurban category developed by Indonesia's Central Agency of Statistics (BPS, Badan Pusat Statistik). I measured rural-urban residence by constructing a dummy variable that indicates whether respondents live in a rural area (coded 1$)$ or in an urban area (coded 0). Examining income level and urban/rural residence simultaneously is particularly important in Indonesia, since poverty is predominantly concentrated in rural areas; in the early $2010 \mathrm{~s}, 16.6 \%$ of rural people were poor, compared with $9.9 \%$ of the urban population (Rural Poverty Portal, 2012). In my sample, which was based on the last census data from the government, $50.2 \%$ of respondents lived in rural areas, while $49.6 \%$ lived in urban areas.

Third, my data source employs education as the final dimension of modernisation, asking respondents about the highest level of education they have completed. Education is coded $1-10$, where 1 indicates that the 
respondent never attended school and 10 indicates that the respondent held a bachelor's or higher degree. A plurality of respondents (41.4\%) reported that they only had primary education, hadn't completed formal education, or had no formal education at all, while $21.1 \%$ reported finishing junior high school, 26.3\% reported finishing senior high school, and $11.1 \%$ reported having higher education.

In addition, the dataset includes other demographic variables such as gender, age, ethnicity, and religion. First, it controls for the respondents' gender to capture any possible relationship between vote buying and gender. Gender is coded 1 if the respondent is a male and 0 if the respondent is a female. As described in Appendix A, the sample was constructed to include $50 \%$ of males and $50 \%$ of females, mirroring the last census data in 2010 . Second, the dataset controls the age of respondents to identify any bias in the tendency of vote buyers to particularly target young (or older) voters. ${ }^{1}$ Age is a continuous variable that reports the respondent's age in years, ranging from the youngest to the oldest. Respondents who were aged 21 years old or less constituted only $4.3 \%$ of the sample, while $44.7 \%$ reported that ages ranging between 22 and 40 years. The percentage of those aged 41 to 55 years accounted for $34.7 \%$, and $16.3 \%$ were older than 55 years.

Another potentially relevant factor predicting vote buying is ethnic identity. Because the Javanese are the largest ethnic group in Indonesia (making up approximately $40 \%$ of the total population), ethnicity is therefore divided into two categories only: Javanese and others. Selfidentification as Javanese was coded as 1 , while others were coded 0 . About $41 \%$ of respondents reported being of Javanese ethnicity. The rest of the respondents identified themselves as non-Javanese; rather, they were affiliated with a large number of small ethnic groups across the archipelago. The last demographic variable is religion. Since other religions are small relative to Islam, ${ }^{2}$ religious affiliation is divided into two categories

\footnotetext{
${ }^{1}$ Some scholars found evidence of a link between age and voters' susceptibility to vote buying (e.g. Brusco et al., 2004). In Argentina, the younger cohorts among low-income Peronists are more likely to receive vote-buying offers than older cohorts. The rationale is that these differences could reflect life-cycle effects, whereby older voters are more likely to be more partisan and have higher party identification levels than younger ones. Their findings support the swing-voter argument, suggesting that political machines tend to target ideologically indifferent voters because they are more dependent on material rewards.

${ }^{2}$ Around 202.9 million people identify themselves as Muslim, which represents $87.3 \%$ of Indonesia's total population today. In my sample, $89.1 \%$ of respondents reported that they were Muslim, 8.4\% were Christian/Catholic, and 2.4\% others. See Appendix A.
} 
only: Islam and others. I constructed a dummy variable where respondents who identify as Muslim were coded 1 and 0 if from a different religion. In the legislative dataset, given that the sample drawn from the majority of provinces in outer islands was small relative to provinces located in Java, the regional variable is divided into two categories: Java and others.

\subsubsection{Civic Engagement}

Putnam and Goss (2002: 10) postulated that networks of civic engagement comprise informal as well as formal organisations. They suggested that such networks don't only take the forms of civic associations but also manifest in informal social engagements such as dinners with friends, gathering in a café, and so forth. Following Mujani (2003), this study examines the degree of civic involvement by establishing the level of respondent's engagement in religious and non-religious organisations. The prompt was the following question: "Allow me to inquire about your participation in any of the following organisations or groups below. Are you an active member, inactive member or non-member of these organisations?" 3 The available choices include religious organisations, such as Nahdlatul Ulama (NU) and Muhammadiyah in the context of Islam or churches in the case of Christianity, or 'secular' associations, such as youth organisations and sport clubs; agricultural and fishermen's groups; and labour unions, political parties, youth community councils (karang taruna), regular social gatherings, cooperatives, art and cultural clubs, and others.

\subsubsection{Political Attitudes}

In the dataset, measures of political attitudes include party identification, efficacy, political interest, political information, political trust, political participation, and support for democracy. In the following sub-sections, I describe in detail the measures developed for each component in the broader area of political attitudes.

\footnotetext{
${ }^{3}$ For coding and scaling purpose, each item of civic engagement comprises a three-point scale: non-member $(0)$, non-active member $(0.5)$, and active member ( 1$)$. Scores for membership in the association are then added up and divided by 12 to create a three-point scale of networks of civic engagement.
} 


\subsubsection{Party Identification}

My post-parliamentary election dataset measures the degree of party identification by using two items. The first question regarding party attachment was: "There are people who feel closer to a certain political party and some who aren't. How about you, do you feel there are any political parties who you feel closer to?" Those who responded affirmatively were asked to name the specific party they feel close to. They were also requested to rate the strength of affiliation to their party on a three-point scale: "How close do you feel toward the party?" In the analysis, overall party identification is an additive scale from these items which is then normalised to a scale of between 1 and 4 , in which 1 indicates respondents who don't feel close at all to any party, 2 indicates those who feel somewhat close, 3 reflects those who feel quite close, and 4 reflects those who feel very close.

\subsubsection{Political Efficacy}

The literature on political behaviour divides political efficacy into two forms: internal and external. The former refers to a citizen's belief that he or she is able to understand politics and influence government decisions, while the latter deals with how a person feels the government will respond to his/her demands (Reef and Knoke, 1999: 414). For internal efficacy, I used responses to the items: (1) "People like me cannot influence decisions by government" and (2) "In general, political issues are too complex, so people like me cannot understand what is going on."4 For external efficacy, I used a single item, asking whether it is true that "people like you aren't heard by political leaders." Each of these items is a four-point scale, with responses ranging from 'strongly disagree' to 'strongly agree.' Since all three questions were negatively keyed, I recoded them with reversed Likert scales. ${ }^{5}$ By reverse-scoring all of the negatively keyed political

\footnotetext{
${ }^{4}$ For further discussion, see Niemi, Craig, and Mattei on "Measuring Internal Political Efficacy in the 1988 National Election Study," The American Political Science Review Vol. 85, 4 (December 1991), pp. 1407-1413.

${ }^{5}$ In statistical analysis, positively keyed items are understood as items that are worded so that an agreement with the item represents a relatively high level of the measured attribute. In contrast, negatively keyed items are defined as those that are worded so that an agreement with the item represents a relatively low level of the measured attribute. The objective of reverse-scoring is to make sure that all the items are consistent with each other-both the originally negatively keyed items and positively keyed items - with regard to the implications of an 'agree' or 'disagree' response. For discussion, see R. Michael Furr's note at http:// psych.wfu.edu/furr/716/Reverse-scoring.doc.
} 
efficacy items, I created consistency among the items. Adding the score of all three items and dividing the result by three produced a four-point scale of political efficacy, which ranged from not efficacious at all (1) to very efficacious (4).

\subsubsection{Political Information}

Political information is measured by responses to five questions. The first question was "How often do you follow the news on politics or government?" with the provided responses ranging through 'every day,' to 'several times in a week, 'once or twice in a week,' 'once or twice in a month,' and 'never.' This question was followed by four additional items that inquired about the intensity with which the respondents followed political news via four different media outlets: TV, radio, newspaper, and the internet. The overall score of measuring political information was drawn from initially reverse-scoring all five items and subsequently obtaining the mean of all of those items.

\subsubsection{Political Interest}

Political interest was measured through a four-point scale of interest in politics or governmental issues. I gauged the extent to which respondents were interested in politics or in governmental issues in general by employing two items. The first was: "How interested are you in politics or governmental issues in general?" Following that, I also asked: "How often do you talk/discuss government issues with other people (family, neighbour, colleague, etc.)?" Because of the nature of these questions, I needed to reverse-score the two items. Finally, I added the score of the two items and divided the result by two, leading a four-point scale of political interest, ranging from not interested at all (1) to very interested (4).

\subsubsection{Political Trust}

To measure political trust in a comparable way, I used a four-point scale constructed from seven items that focused on respondents' level of trust in seven key political institutions. The main question was: "We will mention several institutions. Please rate your level of trust in these institutions: do you possess high trust, moderate trust, little trust, or no trust at all? For each one, please tell me how much trust you have in them: President, People's Consultative Assembly (MPR), People's Representative Council (DPR), judiciary, the armed forces, police, and General Electoral Commission (KPU)." Again, all seven items above were reverse-scored, 
added up, and subsequently divided by seven, establishing a four-point scale of political trust, ranging from no trust at all (1) to high trust (4).

\subsubsection{Political Participation}

For this study, a scale of electoral participation was constructed from a pair of items that indicated whether or not (and if not, why) a citizen participated in the last two legislative elections. The first question was "Did you vote during the 2009 legislative election?" The second was "Did you vote during the legislative election on April 9, 2014?" Each of these two items provided a number of answer choices, varying from 'Yes, I voted,' 'No, I didn't vote,' 'couldn't vote,' to 'refused to vote.' I established turnout as a binary indicator, taking on a value of 1 if the individual voted in the 2009 or 2014 elections, and 0 if the person didn't vote in both elections. The overall political participation score is an additive $0-2$ index, based on the two items described above.

\subsubsection{Democratic Support}

This study used a single standardised item, which was adopted from similar international measures on support for democracy. The question was: "Do you strongly disagree, disagree, agree or strongly agree with this following statement? Compared to other form of governments, democracy is the best form of government for our type of country." As in the original variable, the result is measured on a four-point scale, varying from strongly disagree (1) to strongly agree (4).

\subsection{Results and Discussion: The Determinants of Vote Buying: Who Gets Targeted?}

Having introduced key hypotheses and the measures to verify or falsify them, it is now time to analyse the results regarding the determinants of vote buying based on the post-legislative election survey in 2014. In order to assess the impact of covariates at the individual level, I first present the results from the regression analysis, using individuals' selfreported experiences of vote buying. At the end of the section, I highlight the most striking factor emerging from as being a significant determinant in the targeting of vote buying: party identification. The summary statistics for both dependent variables and covariates are listed in Table 3.1. 
Table 3.1 Descriptive dependent variables and covariates

\begin{tabular}{lccccc}
\hline Variables & Mean & Std. deviation & Min & Max & $\mathrm{N}$ \\
\hline Vote buying & 0.22 & 0.27 & 0 & 1 & 1018 \\
Gender $(1=$ male; $0=$ female $)$ & 0.5 & 0.5 & 0 & 1 & 1212 \\
Rural $(1=$ rural; $0=$ urban) & 0.5 & 0.5 & 0 & 1 & 1212 \\
Age & 42.29 & 13.13 & 16 & 86 & 1211 \\
Education & 4.94 & 2.47 & 1 & 10 & 1210 \\
Income & 6.61 & 3.52 & 1 & 12 & 1205 \\
Javanese $(1=$ Javanese; 0 = otherwise $)$ & 0.41 & 0.49 & 0 & 1 & 1212 \\
Religion $(1=$ Islam; $0=$ otherwise) & 0.89 & 0.31 & 0 & 1 & 1212 \\
Region (Java) & 0.58 & 0.49 & 0 & 1 & 1212 \\
Civic engagement & 0.1 & 0.12 & 0 & 0.63 & 1191 \\
Party ID & 1.29 & 0.73 & 1 & 4 & 1210 \\
Efficacy & 2.36 & 0.5 & 1 & 4 & 979 \\
Political interest & 4.13 & 1.34 & 2 & 8 & 1148 \\
Political information & 2.46 & 0.7 & 1 & 5 & 965 \\
Political engagement & 4.01 & 1.32 & 0.67 & 9.5 & 848 \\
Political participation & 1.81 & 0.45 & 0 & 2 & 1199 \\
Political trust & 2.73 & 0.53 & 1 & 4 & 1074 \\
Democratic support & 2.86 & 0.54 & 1 & 4 & 987 \\
\hline
\end{tabular}

Table 3.2 shows the regression results with respect to vote buying. The dependent variable is the vote-buying index based on responses to all components of this practice (see Chap. 2). I estimated the model using linear regression analysis. ${ }^{6}$ Model 1 of Table 3.2 allows us to assess the role of the modernisation hypothesis and other socio-demographic variables to

${ }^{6}$ To be accepted as a multiple linear regression model assumption, it is first necessary to test the classical assumption, which at least includes a normality test. Based on the results of the normality test I conducted, as can be seen in Appendix D, the residuals weren't normally distributed. Accordingly, I needed to conduct a logistic regression because it doesn't need many of the classic assumption tests (including a normality test) that are required in linear relationships between the dependent and independent variables. In the logistic model, the dependent variable is a dichotomous measure that takes a value of 1 if the respondent received offers of vote buying once/twice, several times, rarely, quite, or very often. The results from both the logistic and linear models are strikingly similar (see Appendix E), suggesting that the linear regression in this case fits just as well as the logistic regression. In this chapter, I decided to report the linear regression model rather than the logistic model for two reasons. First, given that the linear and logistic regression analyses end up with indistinguishable results, the linear model is justifiable. Second, compared to the logistic regression, the linear estimates are easier to interpret (Hellevik, 2007). 


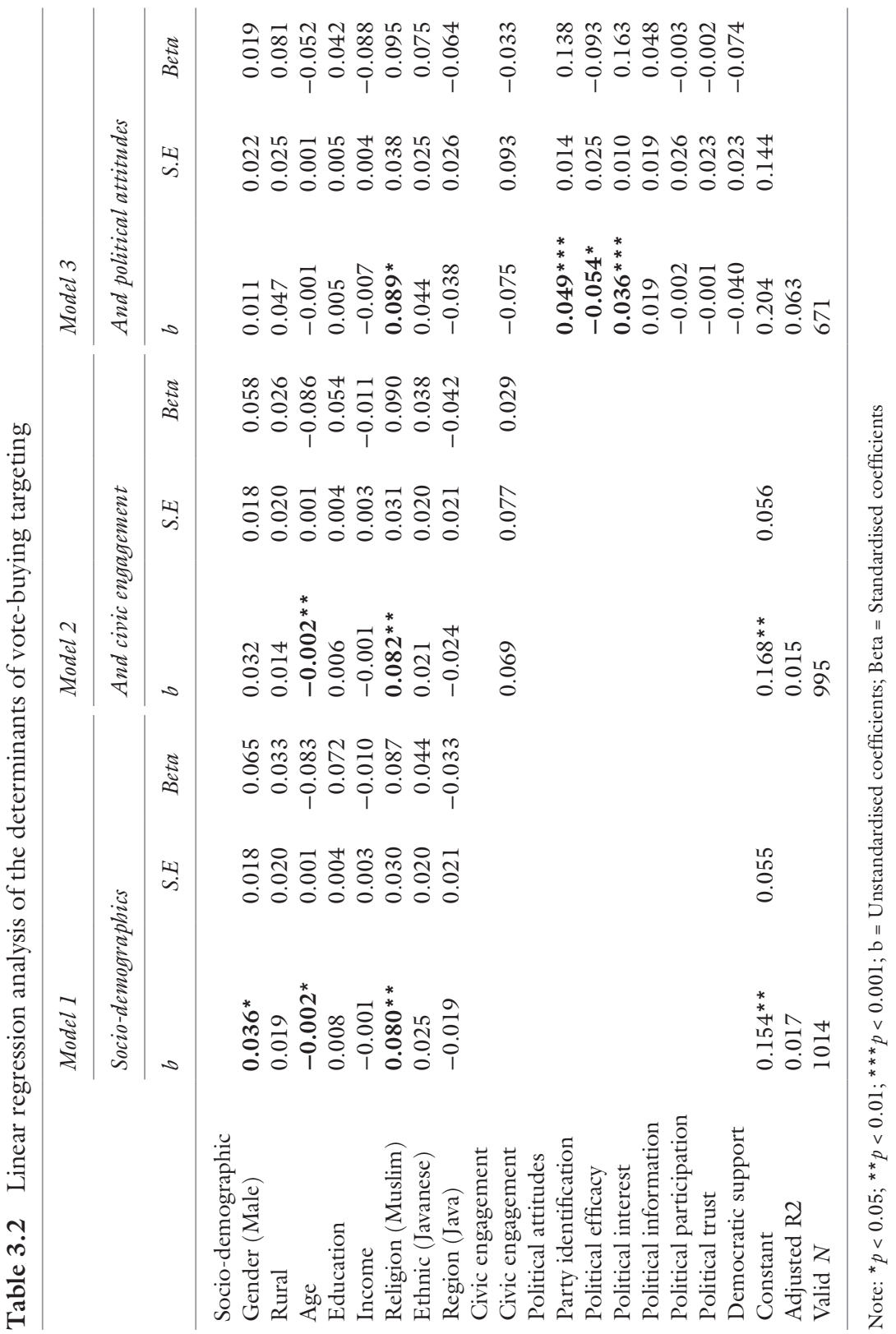


explain the likelihood that an individual is targeted for vote buying. Contrary to the assumptions of numerous scholars, indicators normally advanced to support modernisation arguments about clientelism generally fail to predict the probability that respondents reported being offered benefits in exchange for their votes during the 2014 legislative election. Individual differences in terms of level of income, education, and sociogeographical location didn't make a difference in determining the likelihood that a respondent would be targeted.

Model 1 of Table 3.2 clearly demonstrates that the estimates of these three important measures of modernisation theory (level of income, education, and socio-geographical location) aren't statistically significant in the strictest sense. ${ }^{7}$ When I introduced controls for civic engagement (Model 2) and for a set of political attitudes (Model 3), the magnitudes of these variables remained insignificant.

As indicated above, the insignificance of income and educational factors as well as socio-geographical location tends to contradict the claims of vote-buying scholars who use modernisation theory in their work. Scholars have long suggested that those with lower levels of education will more likely be engaged in quid pro quo exchanges before and during elections (e.g. Kitschelt, 2000; Brusco et al., 2004; Çarkoglu and Aytac, 2015). Equally, it has been claimed that respondents with more education will be less vulnerable to such practices since "as education increases, the life prospects for individuals also increase through better employment and higher incomes" (Sugiyama and Hunter, 2013: 51). Similarly, it is also proposed in the literature that voters who reside in rural areas are more likely to sell their votes (Hicken, 2007a; Jensen and Justesen, 2014; Finan and Schechter, 2012; Vicente, 2013). However, my survey results show that none of these arguments are supported in the case of Indonesia.

More unexpectedly, Model 1 of Table 3.2 also shows that among the socio-demographic variables included in the equation, three variables have a significant relationship with vote buying: gender (male), age, and religion (Muslim). When adding the control variable of civic engagement, as in Model 2 of Table 3.2, the coefficient of male loses statistical significance. In contrast, the magnitude of the age coefficient increases in specification

\footnotetext{
${ }^{7}$ It must be noted that bivariate statistics reveal that vote buying has apparently a significant association with the level of education. But this relationship is spurious given the nonsignificance of the education variable when controlled by other variables. For further discussion on the bivariate results, see Appendix C.
} 
when civic engagement is put into the model. Meanwhile, the coefficient of 'Muslim' remains significant at about the same level of strength-and in the same direction-when the element of civic engagement is included. This confirms the bivariate model suggesting that younger citizens ${ }^{8}$ and Muslims reported statistically significant higher frequencies of vote-buying offers (see Appendix C). However, when I entered a full set of controls (as in the final column of Table 3.2), the only socio-demographic variable that remained statistically significant was that of being Muslim. This significance was at the 0.05 levels. Put differently, being a Muslim significantly predicts a greater probability that a respondent reported electoral handouts, even when a full set of controls was included.

The consistency of this relationship requires investigation. There are two possible explanations. First, there is ample evidence that Muslim candidates and recipients justified vote buying using religious reasoning. Many candidates, either from Islamic or non-Islamic parties, packaged their gifts in religious terms, for example, by describing them as alms (sedekah). Accordingly, the Muslim recipients might not feel that the cash handouts they received were a form of morally questionable 'money politics' but instead viewed them in terms of a 'moral economy of gift giving' (Aspinall et al., 2017: 4). Second, vote buying appears to be endemic among Muslims because traditional patron-client networks-through which candidates' benefits can be delivered-are more prominent in Muslim communities. In particular, many candidates used various deeply entrenched informal social institutions, such as Islamic boarding schools (pesantren), mosques, or religious gatherings (majelistaklim). Importantly, such loose informal networks don't always constitute themselves through official membership and are thus outside of the civic engagement linkages that respondents reported when asked about their membership in social organisations.

While loose social interactions in Muslim society may have played a role in increasing their exposure to clientelistic practices, the overall effect of

\footnotetext{
${ }^{8}$ One potential explanation for this is that young adults are considered to be politically unsettled and thus have weaker political preferences and voting intentions. Opinion polls show, for example, that their intentions to show up at the polls aren't as strong as those of the older voters. According to Indikator's exit poll in the 2014 legislative elections, the proportion of registered 26- to 40-year-olds who turned out to cast their ballot was lower than that of other age groups. These hesitant young voters may create a strong incentive for voteseeking politicians to induce them with benefits. See Indikator's exit poll material release at http://indikator.co.id/uploads/20140411204045.Hasil_EP_Pileg_2014_Update.pdf.
} 
civic engagement on vote buying isn't significant. The regression analysis, as shown in Model 2 of Table 3.2, confirms the bivariate statistics that the substantive effect of civic engagement-measured by membership in social organisations-is statistically insignificant in the strictest sense. ${ }^{9}$ As noted above, much of the literature on electoral clientelism suggests that networks of civic engagement explain the likelihood of being targeted with electoral incentives (Faughnan and Zechmeister, 2011; Callahan, 2005; Brusco et al., 2004; Cruz, 2014). But my analysis suggests that civic engagement in Indonesia has little impact on the individual's propensity to be so targeted. Individuals' involvement in social organisations makes no difference in the probability of them being exposed to vote buying.

What about political attitudes? Three observations stand out in Model 3 of Table 3.2. First, across all components of political attitudes, party identification has a statistically significant and positive relationship with vote buying. The multivariate analysis shows that this partisanship isn't spurious and remains significant and relatively stable regardless of civic engagement, political attitudes, and demographic and socio-economic factors. The effect of party closeness is very large $(p<0.001)$. Extant literature suggests that party affiliation encourages citizens to become politically active. Dalton (2016:8) found that in the US, people with higher party identification are more likely to persuade others, distribute propaganda hats, shirts, and posters, participate in campaign events, or donate to a party's candidate during campaigns. Electoral turnout, Dalton continues, was $26 \%$ higher among strong partisans than among independents. Verba and Nie (1972: 219-220) claim that partisan identification mobilises political activity among lower-status citizens who might otherwise be inactive. The same holds true in other established democracies. Voters with strong party identification voted at a higher rate in the 2009 German Bundestag elections. In addition, they were several times more likely to get involved in campaign rallies and were about twice as likely to try to influence other voters (Dalton, 2016: 8). What stands out about party identification in Indonesia, by contrast, is its strong correlation with experience of vote buying. In crude terms, partisan voters in Indonesia tended to be 'money grubbing' and are significantly more likely to be recipients of material benefits.

Second, defying expectations, the model also shows that political interest is found to be statistically very significant $(p<0.001)$ in explaining the

\footnotetext{
${ }^{9}$ For further discussion on the bivariate results, see Appendix C.
} 
propensity of being offered vote buying. The original relationship between political interest and vote buying remains substantial and significant, even when controlled by all variables in the model. Thus, instead of reducing the individual's propensity to engage in clientelistic practices, political interest serves-in the Indonesian case-as a breeding ground for vote buying. The dominant view among political scientists is that a good citizen in a democratic polity is a citizen interested in and well informed about politics, with strong and stable preferences (e.g. Van Deth, 1983, 1989). The regression analyses of the Indonesian data, however, shows that political interest is positively correlated with a distinctly nondemocratic practice, that is, vote buying.

There are two possible explanations for this rather counter-intuitive finding. First, it is plausible that in the Indonesian case, political interest is an indicator of political alienation. Arguably, those who are interested in politics actually desire to participate in a democratic manner, but that desire is undermined by their perception that the political process doesn't operate justly. This perception, then, makes them increasingly pragmatic at election time (this interpretation is supported by the analysis of the efficacy measure below). Another possible explanation for the link between political interest and vote buying has been suggested by Guardado and Wantchekon (2014: 7). They propose that exposure to electoral handouts is endogenous to voters' political interest. Based on their theory, if voters are highly interested in politics, they are likely to get involved in more political activities than others. This, in turn, increases their likelihood of being offered a reward by political operatives they come into contact with.

Finally, consistent with prior expectations (and as indicated above), regression results reveal that political efficacy stands out as a strong predictor of vote buying. The variable of efficacy presents a negative coefficient and is in the expected direction, implying that less efficacious individuals are more likely to receive offers of vote buying. The reverse is also true: those with higher efficacy are less likely to engage in such practice. Of course, this finding is neither new nor surprising, given that the existing literature on clientelism has long suggested such a relationship (e.g. Banegas, 1998; Kerkvliet, 1991; Schaffer and Schedler, 2007). By contrast, other political attitudes have little effect in determining vote buying in Indonesia, including support for democracy or political (i.e. electoral) participation, which I had earlier hypothesised would show correlations with vote-buying experience. Indonesian respondents supporting democracy aren't more or less likely to engage in vote buying than those who 
don't, and electoral participation is no reliable predictor of such engagement either.

Having established the regression results with respect to vote buying at the national legislative election, we now need to highlight the most salient issue found as being significant in such electoral setting. The finding is clear: party identification has a strong, consistent, direct, positive, and highly significant effect on an individual's propensity to receive offers of vote buying. This effect remains significant, regardless of socio-economic factors, civic engagement, and political attitudes. In other words, a voter's partisanship consistently and significantly predicts the likelihood of being offered vote buying in Indonesia. Other factors stand out as well-such as being Muslim - but in the largest Muslim nation on the globe, this isn't a theoretically challenging finding.

On the other hand, the finding, that party loyalists are the primary targets of vote buying, obviously contrasts with the swing-voter model, which proposes that parties or candidates will not waste their vote-buying efforts on already locked-in partisans (see Chap. 1). As I will argue in the following chapter, the underlying logic behind candidates' decision to target loyalists is that they are safe bets, or a good return on a limited investment. By contrast, from the candidates' perspective, targeting non-partisans is a risky enterprise. Hence, investing in party loyalists is a function of candidates' attempts to manage and mitigate electoral uncertainty. A widely held view among candidates and brokers is that because electoral competition has become increasingly competitive after the introduction of the open-list PR system, and in an environment where electoral participation is optional and the ballot is secret, it is important to target 'loyal' or 'base' voters, and of course party loyalist form a large subset within this group.

\subsection{Conclusion}

At the beginning of this chapter, I developed a number of hypotheses on who is most likely to be targeted by vote-buying efforts. These hypotheses were drawn from the main streams of the vote-buying literature. Let us now review systematically whether these hypotheses hold. It is clear that factors derived from modernisation theory have little effect in determining an individuals' propensity to experience vote buying in the national legislative election. One of the most common measures of modernisation theory is education. Some assume that better educated voters are less 
likely to engage in vote buying, partly because they understand that the practice undermines democracy and partly because they are economically better off. But in the case of Indonesia, there are no significant differences by educational level in the receipt of electoral incentives.

Another surprising result is the insignificance of poverty. One of the strongest findings in prior research on clientelism is that poorer voters are more susceptible to vote buying because even small transfers are valuable to them. In Indonesia, however, vote buying has no significant relationship with poverty. Similarly, vote buying in the country didn't differ between rural and urban regions. Additionally, this study explored whether civic engagement can explain the likelihood of being offered vote buying in the run-up to the 2014 legislative election. This hypothesis, however, is mostly denied in the case of Indonesia. Involvement in social organisations didn't make a difference in terms of whether citizens received offers of vote buying or not.

With respect to specific hypotheses relating to political attitudes, I expected, drawing from the swing-voter model, that party identification levels would be negatively associated with the likelihood of experiencing vote buying. In other words, I hypothesised that the more non-partisan voters were, the more likely they would be to receive vote-buying offers. In the case of Indonesia, however, the opposite turns out to be true: partisan voters are proportionally more likely to receive vote-buying offers than non-partisans. In terms of political efficacy, I expected to find that feelings of political alienation increase the likelihood of exposure to clientelist exchanges (Reef and Knoke, 1999: 414). Using Indonesia's 2014 legislative election, I verified this hypothesis. Another element of political attitude dimension is political interest. I expected to find that the more uninterested a citizen in politics, the more vulnerable they would be to vote buying. Against expectations, instead of interest in politics predicting less exposure to vote buying, it increased it. Interest in politics significantly predicts the probability that someone would report vote buying. Another important political attitude is political trust. People with lower political trust are believed to be more unlikely to trust democratic institutions, and they are therefore more likely to build transactional relationships with political parties or candidates (as indicated above, this is similar to arguments surrounding efficacy, but political trust is a more abstract concept). If this claim is true, I expected to find that citizens with less trust in political institutions to be more likely to engage in vote buying. In the Indonesian case, this hypothesis isn't falsified since the bivariate and mul- 
tivariate models found no evidence; there was simply no relationship to clientelism. Further, there is also no statistically significant relationship between vote buying and electoral participation, political information, and support for democracy.

Given the strong evidence for the importance of party identification in predicting the likelihood of a voter being targeted by vote buying, the remainder of this book focuses on how exactly such party-based partisanship affects electoral patronage distribution. The finding that party affiliation significantly attracts benefits raises further puzzles. First, why do parties and candidates disproportionately target party loyalists with their favours? As indicated, this finding runs counter to prior research done by advocates of the swing-voter argument, who suggest that such persons are already captive voters and will support their party no matter what. Second, if partisans are indeed the preferred vote-buying target, how feasible is it for candidates to win only by targeting such voters? How many partisan voters are there, and how does their number affect further efforts to theorise vote-buying patterns in Indonesia? The next chapter addresses these questions.

\section{BIBLIOGRAPHY}

Books, Journal Articles, and Unpublished Papers

Allen, N.W. (2015) Clientelism and the Personal Vote in Indonesia. Electoral Studies 37: 73-85.

Almond, G.A. and Verba, S. (1963) The Civic Culture: Political Attitudes and Democracy in Five Nations. Princeton, NJ: Princeton University Press.

Amick, J. (2016) Cash or Carry? Targeting Low Income Voters in Mayoral Election. Paper presented for SEAREG Meeting, 3-4 June, University of Michigan, U.S.

Andrews, J.T. and Inman, K. (2009) Explaining Vote Choice in Africa's Emerging Democracies. Paper presented at Midwest Political Science Association.

Aspinall, E. (2014) When Brokers Betray: Social Networks and Electoral Politics in Indonesia. Critical Asian Studies 46(4): 545-570.

Aspinall, E. and Sukmajati, M. (eds) (2016) Electoral Dynamics in Indonesia: Money Politics, Patronage and Clientelism at the Grassroots. Singapore: NUS Press.

Aspinall, E., Rohman, N., Hamdi, A.Z., Rubaidi, and Triantini, Z. (2017) Vote Buying in Indonesia: Candidate Strategies, Market Logic and Effectiveness. Journal of East Asian Studies 17: 1-27. 
Banegas, R. (1998) Marchandisation du vote, citoyennete et consolidation democratique au Benin. Politique Africaine 69(1): 75-88.

Blaydes, L. (2011) Elections and Distributive Politics in Mubarak's Egypt. New York: Cambridge University Press.

Bratton, M. (2008) Vote Buying and Violence in Nigerian Election Campaigns. Electoral Studies 27(4): 621-632.

Brusco, V., Nazareno, M., and Stokes, S. (2004) Vote Buying in Argentina. Latin American Research Review 39(2): 66-88.

Callahan, W.A. (2005) Social Capital and Corruption: Vote Buying and the Politics of Reform in Thailand. Perspective on Politics 3(3): 495-508.

Çarkoglu, A. and Aytac, S.E. (2015) Who Gets Targeted for Vote Buying? Evidence from an Augmented List Experiment in Turkey. European Political Science Review 7(April): 1-20.

Carreras, M. and Irepoglu, Y. (2013) Trust in Elections, Vote Buying, and Turnout in Latin America. Electoral Studies 32: 609-619.

Citrin, J. and Muste, C. (1999) Trust in Government. In: J.P. Robinson, P.R. Shaver, and L.S. Wrightsman (eds) Measures of Political Attitudes. San Diego: Academic Press.

Cox, G.W. and McCubbins, M.D. (1986) Electoral Politics as a Redistributive Game. The Journal of Politics 48(2): 370-389.

Cruz, C. (2014) Social Networks and Illegal Electoral Strategies. PhD dissertation, University of California San Diego, San Diego.

Dalton, R.J. (2016) Party Identification and Its Implications. Politics: Oxford Research Encyclopedias. USA: Oxford University Press.

Diaz-Cayeros, A., Estévez, F., and Magaloni, B. (2012) Strategies of Vote Buying: Democracy, Clientelism and Poverty Relief in Mexico. Viewed at https://web. stanford.edu/ magaloni/dox/2012strategiesvotebuying.pdf. Accessed 17 October 2015.

Dixit, A. and Londregan, J. (1996) The Determinants of Success of Special Interests in Redistributive Politics. Journal of Politics 58(4): 1132-1155.

Faughnan, B.M. and Zechmeister, E.J. (2011) Vote Buying in the Americas. AmericasBarometer Insights 57: 1-8.

Finan, F. and Schechter, L. (2012) Vote Buying and Reciprocity. Econometrica 80(2): 863-881.

Furr, R.M. No Date. Negatively-Keyed Items and Reverse-Scoring. Department of Psychology Wake Forest University. Viewed at http://psych.wfu.edu/ furr/716/Reverse-scoring.doc. Accessed 8 July 2016.

Gans-Morse, J., Mazzuca, S., and Nichter, S. (2014) Varieties of Clientelism: Machine Politics during Elections. American Journal of Political Science 58(2): $415-432$.

Gonzalez-Ocantos, E., de Jonge, C.K., Meléndez, C., Osorio, J., and Nickerson, D.W. (2012) Vote Buying and Social Desirability Bias: Experimental Evidence from Nicaragua. American Journal of Political Science 56(1): 202-217. 
Grossman, G.M. and Helpman, E. (1996) Electoral Competition and Special Interest Politics. Review of Economic Studies 63: 265-286.

Guardado, J. and Wantchekon, L. (2014) Do Electoral Handouts Affect Voting Behavior? Working Paper No. 171, Afrobarometer.

Hellevik, O. (2007) Linear versus Logistic Regression when the Dependent Variable is a Dichotomy. Quality \& Quantity 43(1): 59-74. Viewed at https:// doi.org/10.1007/s11135-007-9077-3. Accessed 11 May 2017, 2 February 2016.

Hicken, A. (2011) Clientelism. Annual Review Political Science. Viewed at http://www.annualreviews.org/doi/abs/10.1146/annurev. polisci.031908.220508. Accessed 9 May 2015.

- (2007a) How Do Rules and Institutions Encourage Vote Buying? In: F.C. Schaffer (ed) Elections for Sale: The Causes and Consequences of Vote Buying. Colorado: Lynne Rienner Publisher, Inc.

- (2007b) How Effective are Institutional Reforms? In: F.C. Schaffer (ed) Elections for Sale: The Causes and Consequences of Vote Buying. Colorado: Lynne Rienner Publisher, Inc.

Inglehart, R. (1999) Trust, Well-Being, and Democracy. In: M.E. Warren (ed) Democracy and Trust. Cambridge: Cambridge University Press.

Jensen, P.S. and Justesen, M.K. (2014) Poverty and Vote Buying: Survey-based Evidence from Africa. Electoral Studies 33: 220-232.

Keefer, P. (2007) Clientelism, Credibility, and the Policy Choices of Young Democracies. American Journal of Political Science 51(4): 804-821.

Kerkvliet, B.J. (1991) Understanding Politics in a Nueva Ecija Rural Community. In: B. Kerkvliet and R. Mojares (eds) From Marcos to Aquino: Local Perspectives on Political Transition in the Philippines. Honolulu: University of Hawaii Press.

Kitschelt, H. (2000) Linkages between Citizens and Politicians in Democratic Polities. Comparative Political Studies 33: 845-879.

- (2007) The Demise of Clientelism in Affluent Capitalist Democracies. In: H. Kitschelt and S. Wilkinson (eds) Patrons, Clients, and Policies: Patterns of Democratic Accountability and Political Competition. Cambridge, UK: Cambridge University Press.

Kitschelt, H. and Wilkinson, S. (2007) Patrons, Clients, and Policies: Patterns of Democratic Accountability and Political Competition. Cambridge, UK: Cambridge University Press.

Lindbeck, A. and Weibull, J.W. (1987) Balanced-budget Redistribution as the Outcome of Political Competition. Public Choice 52: 273-297.

Lipset, S.M. (1959) Some Social Requisites of Democracy: Economic Development and Political Legitimacy. The American Political Science Review 53(1): 69-105.

Manzetti, L. and Wilson, C. (2009) Why Do Corrupt Governments Maintain Public Support? In: C. Blake and S. Morris (eds) Corruption and Democracy in Latin America. Pittsburgh: University of Pittsburgh Press. 
Mujani, S. (2003) Religious Democrats: Democratic Culture and Muslim Political Participation in Post-Suharto Indonesia. PhD dissertation, Ohio State University, $\mathrm{OH}$.

Nichter, S.C. (2008) Vote Buying or Turnout Buying? Machine Politics and the Secret Ballot. American Political Science Review 102(1):19-31.

Niemi, R.G., Craig, S.C., Mattei, F. (1991) Measuring Internal Political Efficacy in the 1988 National Election Study. The American Political Science Review 85(4):1407-1413.

Putnam, R.D. (1993) Making Democracy Work: Civic Traditions in Modern Italy. Princeton: Princeton University Press.

Putnam, R.D. and Goss, K.A. (2002) Introduction. In: R.D. Putnam (ed) Democracies in Flux: The Evolution of Social Capital in Contemporary Society. Oxford: Oxford University Press.

Reef, M.J. and Knoke, D. (1999) Political Alienation and Efficacy. In: J.P. Robinson, P.R. Shaver, and L.S. Wrightsman (eds) Measures of Political Attitudes. San Diego: Academic Press.

Rural Poverty Portal. (2012) Rural Poverty in Indonesia. IFAD (International Fund for Agriculture Development). Viewed at http://www.ruralpovertyportal.org/country/home/tags/indonesia.html. Accessed 20 June 2015.

Schaffer, F.C. and Schedler, A. (2007) What is Vote Buying? In: F.C. Schaffer (ed) Elections for Sale: The Causes and Consequences of Vote Buying. Boulder: Lynne Reinner.

Scott, J. (1972) Patron-Client Politics and Political Change in Southeast Asia. The American Political Science Review 66(1): 91-113.

Stokes, S.C. (2005) Perverse Accountability: A Formal Model of Machine Politics with Evidence from Argentina. American Political Science Review 99(3): $315-325$.

- (2007a) Is Vote Buying Undemocratic? In: F.C. Schaffer (ed) Elections for Sale: The Causes and Consequences of Vote Buying. Colorado: Lynne Rienner Publisher, Inc.

- (2007b) Political Clientelism. In: C. Boix and S. Stokes (eds) The Oxford Handbook of Comparative Politics. New York: Oxford University Press.

Stokes, S.C., Dunning, T., Nazareno, M., and Brusco, V. (2013) Brokers, Voters and Clientelism: The Puzzle of Distributive Politics. New York: Cambridge University Press.

Sugiyama, N.B. and Hunter, W. (2013) Whither Clientelism? Good Governance and Brazil's Bolsa Família Program. Comparative Politics 46(1): 43-62.

Tawakkal, G., Suhardono, W., Garner, A., and Seitz, T. (2017) Consistency and Vote Buying: Income, Education, and Attitudes about Vote Buying in Indonesia. Journal of East Asian Studies 17(3): 313-329. 
Van Deth, J.W. (1983) The Persistence of Materialist and Postmaterialist Value Orientation. European Journal of Political Research 11: 63-79.

- (1989) Interest in Politics. In: K. Jenings and J.W. Van Deth (eds) Continuities in Political Action. New York: Walter de Gruyter.

Verba, S. and Nie, N. (1972) Participation in America. New York: Harper and Row.

Verba, S., Schlozman, K.L., and Brady, H.E. (1995) Voice and Equality: Civic Voluntarism in American Politics. Cambridge: Harvard University Press.

Vicente, P.C. (2013) Is Vote-buying Effective? Evidence from a Field Experiment in West Africa. The Economic Journal. Viewed at http://onlinelibrary.wiley. com/doi/ 10.1111/ecoj.12086/pdf. Accessed 17 September 2013.

Vicente, P.C. and Wantchekon, L. (2009) Clientelism and Vote Buying: Lessons from Field Experiments in African Elections. Oxford Review of Economic Policy 25(2): 292-305.

Open Access This chapter is licensed under the terms of the Creative Commons Attribution 4.0 International License (http://creativecommons.org/licenses/ by $/ 4.0 /)$, which permits use, sharing, adaptation, distribution and reproduction in any medium or format, as long as you give appropriate credit to the original author(s) and the source, provide a link to the Creative Commons licence and indicate if changes were made.

The images or other third party material in this chapter are included in the chapter's Creative Commons licence, unless indicated otherwise in a credit line to the material. If material is not included in the chapter's Creative Commons licence and your intended use is not permitted by statutory regulation or exceeds the permitted use, you will need to obtain permission directly from the copyright holder.

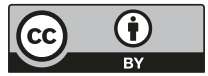

